\title{
Reconceptualising Film Policies
}

Edited by Nolwenn Mingant and Cecilia Tirtaine

\footnotetext{
$\underset{\text { Taylor \& Francis Group }}{\text { Routledge }}$ NEW YORK AND LONDON
} 
First published 2018

by Routledge

711 Third Avenue, New York, NY 10017

and by Routledge

2 Park Square, Milton Park, Abingdon, Oxon OX14 4RN

Routledge is an imprint of the Taylor \& Francis Group, an informa business

(C) 2018 Taylor \& Francis

The right of the editors to be identified as the authors of the editorial material, and of the authors for their individual chapters, has been asserted in accordance with sections 77 and 78 of the Copyright, Designs and Patents Act 1988.

All rights reserved. No part of this book may be reprinted or reproduced or utilised in any form or by any electronic, mechanical, or other means, now known or hereafter invented, including photocopying and recording, or in any information storage or retrieval system, without permission in writing from the publishers.

Trademark notice: Product or corporate names may be trademarks or registered trademarks, and are used only for identification and explanation without intent to infringe.

Library of Congress Cataloging in Publication Data [CIP data]

ISBN: 978-1-138-72930-8 (hbk)

ISBN: 978-1-315-18993-2 (ebk)

Typeset in Sabon by codeMantra 


\section{Contents}

List of Figures and Tables $\quad$ ix

Foreword xi

Acknowledgements xiii

Introduction 1

NOLWENN MINGANT AND CECILIA TIRTAINE

\section{PART I}

The Traditional Film Policy Paradigm

Introduction by Nolwenn Mingant and Cecilia Tirtaine

1 'France needs to position itself on the global media map, as a cultural reference and a production centre.'

AN INTERVIEW WITH STEPHAN BENDER

2 A Fragile Industry: Government Policy and Dubbing in Quebec

A CASE STUDY BY CHRISTINE YORK

3 Monitored Relations: The US Film Industry, Chinese Film Policy and Soft Power

DERON OVERPECK

4 Cool Japan and Heated Politics: Japanese Film and Media Policies within the Economic Politics of Global Markets

JENNIFER DEWINTER

5 'Sophisticated Cyber Terrorists': The Film Industry, Rhetoric and National Security 
vi Contents

6 National Film Policies: Discourses and Loopholes

A CASE STUDY BY JOËL AUGROS

PART II

The Film Policy Power Struggle

Introduction by Nolwenn Mingant and Cecilia Tirtaine

7 'Qualified personalities': Sociology of the French 'Media Government' from Cinema to the Digital Era

OLIVIER ALEXANDRE

8 Informal Collaborations and Formal Agreements:

Chinese-Korean Film Encounters

BRIAN YECIES

9 'The Petrol in Our Tank': Public-Private Collaboration in Indian State Animation, Visual Effects, Gaming and Comics (AVGC) Policy

TIMOTHY JONES

10 'Unionisation of visual effects is inevitable'

AN INTERVIEW WITH JOE PAVLO

11 Tiptoeing the Red Line: PureMovies and Censorship in China

A CASE STUDY BY TIECHENG LI

12 Bridging the Gap: Towards a Dialogue between Screen Production, Policy and Scholarship

JULIA HAMMETT-JAMART

\section{PART III}

The Film Policy Tangle

Introduction by Nolwenn Mingant and Cecilia Tirtaine

13 The Ibermedia Programme: How Supra-National Policy Developed the Ibero-American Audiovisual Space 
15 'I have to make a round of every country's funding systems.'

AN INTERVIEW WITH PRODUCER SABINE SIDAWI

16 Cross-Border Collaboration: Subnational Film Policies and Cultural Frameworks in Belgium and France JAMIE STEELE

17 Between YU and the EU: The Europeanisation of the Serbian Film Policies

PETAR MITRIC

18 Reconciling Economic and Cultural Goals in Film Policy: Propositions from Europe

A CASE STUDY BY ANNA HEROLD AND CLAUDIA GOLSER

\section{PART IV}

(Re)Inventing the Film Policy Paradigm

Introduction by Nolwenn Mingant and Cecilia Tirtaine

19 Talking to Netflix with a Canadian Accent: On Digital Platforms and National Media Policies

IRA WAGMAN

20 One Script, Several Films: Public Policies and the Digitisation of Movie Theatres in the United States, France and Quebec AURÉLIE PINTO

21 Unwilling and Powerless: Facing Illegal Distribution and Exhibition in Chad

A CASE STUDY BY PATRICK NDILTAH

22 From Film Policy to Creative Screen Policies: Media Convergence and Film Policy Trends in Flanders

A CASE STUDY BY GERTJAN WILLEMS, DANIEL BILTEREYST, PHILIPPE MEERS AND ROEL VANDE WINKEL

23 South African Post-Apartheid Film Policy: Shifting Discourses on Film, National Identity and Cultural/ Creative Industries 
viii Contents

24 The Vertical Axis of Film Policies in Europe: Between Subsidiarity and Local Anarchy MARCO CUCCO

25 The Film Code 'will promote the development of the film industry and make Togolese cinema visible and competitive internationally'

AN INTERVIEW WITH KOMI ATI

26 Films ex-nibilo: Abu Dhabi's 'Greenfields Film and Media Policy Model'

NOLWENN MINGANT

List of Contributors

Index 


\title{
Introduction
}

\author{
Nolwenn Mingant and Cecilia Tirtaine
}

\section{6-2017: A Changed Context}

In 1996, Albert Moran edited the groundbreaking volume Film Policy: International, National and Regional Perspective. The mid-1990s was a timely moment to assess the history and challenges of film policies around the world, after the sudden acceleration of globalisation, the development of new information technologies and the opening up of former Communist territories to liberal ideologies. Moran's volume records not only the interrogations linked with the triumphant globalisation of the 1990s, but also the legacy of thirty years of debates about film, culture and economics. In the 1970s, the 'cultural imperialism' and 'cultural dependency' theories brought to the fore the link between cultural products and the circumstances of their production and distribution. Observers such as Schiller, Mattelart and Tunstall emphasised the imbalance in the flow of information and the complete domination of the South by Northern media and programmes. In 1982, UNESCO (United Nations Educational, Scientific and Cultural Organization) asked for a 'New World Information and Communication Order'. At the Mexico Summit, Western countries such as France joined the debate and blamed the US for being the main centre of media imperialism (Tomlison 1991). In the early 1990s, tensions reached their apex during two free trade negotiations between the US and two Western countries, Canada and France. In 1992, Canadian film professionals wrestled to have film 'exempted' from the Free Trade Agreement with Canada. This exemption was subsequently maintained during the NAFTA (North American Free Trade Agreement) negotiations in 1993. In Europe, 1993 is the year of the GATT (General Agreement on Tariffs and Trade) negotiations, in which the United States was faced with - and had to give in to - a French-led outcry to defend 'cultural exception'. Moran's edited volume is a product of these tense times and its main focus is the Hollywood domination of the world film and media market. National film policies are implicitly defined as a response to this domination and an attempt to defy Hollywood through the creation and support of domestic film production. 


\section{Nolwenn Mingant and Cecilia Tirtaine}

Twenty years after the publication of Film Policy, the international film and media landscape has drastically evolved. Globalisation has become further entrenched and has changed the way films are made, intimately intertwining film industries around the world. The growing wave of runaway productions in the 1990s has led Miller et al. to coin the concept of 'New International Division of Cultural Labour', 'to account for the differentiation of cultural labour, the globalisation of labour processes, the means by which Hollywood coordinates and defends its authority over cultural labour markets and the role national governments play in collusion with MNCs' (Miller et al. 2011, 52). This, however, has evolved over the past two decades, as production centres around the world have turned the system to their own advantage. In 2010, Goldsmith, Ward and O'Regan showed that the 'contemporary phenomenon of globally dispersed high-budget film and television production' now rests on a balance between the interests of the Hollywood 'design centre' and state-defended 'location interests' (Goldsmith et al. 2010, 2, 19). The textbook example of a country turning the new production patterns to its advantage is the appearance of New Zealand on the world film map in the wake of the production of Peter Jackson's Lord of the Rings trilogy (2001-2003). In the same way, television series Game of Thrones (HBO, 2011-) has brought attention to Northern Ireland. The race to become an attractive production centre - and reap the economic and symbolic benefits - is currently run at the national level, but also at local levels, from German Länder to British cities, which develop their own programmes to attract film activity.

Historical film industries have also gained strength (Hill and Kawashima 2016, 667). India is now the most prolific producer in the world. The Republic of China is experiencing a production boom, and Brazil is heading towards a renaissance (Dagnaud 2011). The economic interpenetration characteristic of the early twenty-first century also played out in the world of cinema, with a phenomenon of cross-investing at the sectorial level, as Hollywood studios invest in Chinese and Indian companies, while companies such as the Chinese Alibaba, Shanghai Film Group (SFG) or Huahua Media, and the Indian Reliance invest in Hollywood. Official co-productions increasingly act as an instrument of integration. Over the past ten years, India has thus signed agreements with Western countries (United Kingdom, Canada, France, Germany, Italy, Spain, New Zealand, Poland), as well as with other emerging countries (Brazil, China, South Korea), in a logic that mixes North-South and South-South networking (Vlassis 2016).

In this context, Mingant notes that three factors were instrumental in pushing Hollywood to open up to international influences: the failure of Hollywood's - and the Motion Picture Association of America's - traditional strong-armed policies in the FTA and GATT negotiations forced it to embrace international cooperation; the 
development of new communication technologies made runaways possible and profitable; the development of a strong international audience through the opening of the former Communist countries and new platforms (VHS, DVD, etc.) led to favouring a new Hollywood genre, the 'global-local film' (Mingant 2010, 2011). While the US film production centre remains dominant today, the word 'Hollywood' covers a reality that is very different from what it was twenty years ago. Far from being the strong-willed archenemy to fight, Hollywood has now become a partner not only to collaborate with, but also to use in order to pursue one's own objectives. It sometimes also stands as a mere background context for policy-makers intent on devising national policies centred on their own domestic and regional context. African policy-makers, for example, have been less concerned with Hollywood ventures than with the development of alternative film production and distribution models linked to technological possibilities. Nigeria stands as a symbolic model, with the rise of locally-targeted Nollywood with the development of the VHS in the early 1990s and its transformation into a more internationally-targeted New Nollywood with the use of the internet in the second half of the 2000s (Jedlowksi 2015, 76-7), but many African countries today are grappling with local film issues, notably piracy and film education. Today, while the film world has become more competitive, myriad situations exist in film industries around the world that vie for existence and recognition. Moving away from the more exclusive concepts of 'exemption' and 'exception', UNESCO gave this phenomenon symbolic recognition with the 2011 adoption of the Universal Declaration on Cultural Diversity.

\section{The Twenty-First Century Challenges of Globalisation}

This volume is intentionally stepping away from a US-centred approach to refocus on other countries and industries around the world, to better reflect the varieties of connecting lines that exist today. Specific relations exist between countries within areas sharing the same language, such as the Francophone countries or the Hispanic sphere. Asian countries have their own webs of collaboration and competition that deserve specific attention. Countries in Africa and the Middle East face unique challenges. The geographical dimension of globalisation is actually an issue where complexity has increased over the past twenty years. In his introduction to Film Policy, Moran warns that the book's division into three perspectives, 'international, national and regional', was more for the sake of convenience than to prove a theoretical point, since 'it was found that it was not so easy to delineate between these three levels. In the world of the very late twentieth century, film policy inevitably has ramifications at many levels' (Moran 1996, 12). Today, the intertwining between these many levels is stronger than ever. It has also become 


\section{Nolwenn Mingant and Cecilia Tirtaine}

more challenging with the development of film initiatives at each level of policy-making. What Moran called the 'international' or 'global' level, and will be defined in this volume as 'supranational', are institutions or agreements that bind several states. This includes, for example, not only the World Trade Organisation and the European Union, but also the mesh of free trade agreements between two or more nations that has exponentially increased over the past decades. When supranational organisations correspond to a clearly delineated geographical area, they are usually called 'regional', in line with the economic 'regional integration' terminology. The level of 'national film policies' covers the specific limits of one individual country, and 'national cinema' is often used as a synonym for 'domestic film industry' (Moran 1996, 8). As Moran notes, however, the term 'national cinema' must be used with caution, in part because it promotes one vision of the nation and erases any 'sub-national and multicultural perspectives' (Moran 1996, 10). The third section of Moran's book deals with 'intranational perspectives', i.e. policies taken at a local level. The development of intranational policies, at the level of a region, a local state or even a city, is largely a consequence of the development of the globally dispersed production phenomenon. In order to avoid the ambiguity of the word 'regional', sometimes used to define specific regions within a country, most of the authors of this volume will be using terms such as 'local' or 'infranational'. The continued existence of national intervention in the film industry, combined with the proliferation of supra- and infranational initiatives has made policy-making more complex in a world characterised by the bloated profusion of policies.

Policy-making has also become increasingly complex due to the dramatic development of technology. While information technology had engine-started globalisation in the 1980s, the development of the internet was a major game-changer, to the point that the concepts of 'Digital Revolution' or 'Digital Turn' have been coined to define the new technological order. In the 1990s, the 'digital revolution paradigm presumed that new media would displace old media' (Jenkins 2006, 6). In the early decades of the twenty-first century, however, the paradigmatic shift that has been observed had less to do with revolution and more with convergence. As Iosifidis notes, convergence 'between the information technology (IT), telecommunications and media sectors' started in the 1960s, but 'recent technological advances, such as digitalisation, compression, developments and the internet, have accelerated the scope of convergence potential' (Iosifidis 2011, 169-170). This multifaceted phenomenon, whose most visible facet is technological convergence, also includes convergence at the industrial level between technology, content and internet companies (Iosifidis 2011, 174), and market convergence such as 'interactive digital television' (Iosifidis 2011, 180). This also entails a change in practice with the phenomenon of 'publisher-user convergence or producer-consumer convergence' (Iosifidis 2011, 180). This has, in turn, led to the development 
of what Jenkins calls a 'convergence culture, where old and new media collide, where grassroots and corporate media intersect, were the power of the media producer and the power of the media consumer interact in unpredictable ways' (Jenkins 2006, 2).

One way open for policy-makers to grapple convergence has been to use concepts which subsume individual film policies, broadcasting policies and so forth, in larger entities, notably those of 'cultural industries', i.e. 'industries which combine the creation, production and commercialisation of creative contents which are intangible and cultural in nature', such as publishing, film and design; and the 'term creative industries encompasses a broader range of activities which include the cultural industries plus all cultural or artistic production, whether live or produced as an individual unit', such as architecture and advertising (UNESCO 2006, 3). Another term used by policy-makers has been 'screen industry', which focuses on all 'businesses and activity involved in creating screen content (production and post-production), and the display of such works (distribution, exhibition, and broadcasting)' (Statistics New Zealand 2013-2014). In actual fact, however, these terms are not used uniformly across the world. While New Zealand favours the 'screen industry' appellation, the United Kingdom and Australia use 'creative industries'. These concepts can also cover different realities as they are imported into each specific national context. At a time when policy-makers have to reconceptualise the terms and means of their actions, observing, defining and studying film policies is vital, not only because film policies are all around us, but also because they are extremely political.

\section{Policies, Players and Politics}

The choice to make film policies the topic of this volume does not derive from any twentieth-century nostalgia or backward-looking attitude, but from the realisation that by subsuming film into screen, creative or cultural industries, one tends to lose track of the long-term evolution of the film world. While all-encompassing, these terms are also vague and can obfuscate actual policies and issues. Thus, authors in this volume will relentlessly follow the film track, as it winds in the meanders of twenty-first-century globalisation. While film support mechanisms are the most visible type of film policy, they are only the tip of the iceberg, and the volume will tend to favour areas in which support does exist but is currently understudied. Here, 'film policy' will be defined as any type of state intervention in any of the following key areas regarding film: development (film agency grants, film festival workshops, etc.), production (shooting and working permits, tax incentives, script censorship, etc.), distribution (ratings systems, quotas, copyright, etc.), exhibition (box-office taxes, ticket price regulation, safety measures, etc.) and promotion (film festivals, export agencies, official reports, etc.), and 


\section{Nolwenn Mingant and Cecilia Tirtaine}

also training and education (film schools, academic Film Studies departments, etc.), as well as preservation (cinémathèques, national film centres, archives, etc.).

As is the case for media policy in general, the 'state has been a central actor in two ways: as the arena for articulating and negotiating public demands, and as a set of institutions responsible for passing and enforcing policies affecting media systems within a limited geographical territory' (Waisbord 2016, 38). Discourse formulation and policy implementation is undeniably specific to each country. While some countries adopt an interventionist, hands-on approach, from the creation of a strong support system in post-World War II France to the nationalised film industry of the USSR, others favour a more economically liberal, hands-off approach. Within their preferred approach at any given time, states will also create a mix of restrictive measures (e.g. quotas) and supporting measures (e.g. production subsidies) (Johnson 1996, 135). Flibbert, however, warns against the temptation of considering the state as a fully coherent monolithic entity: trade and cultural policies can, for example, contradict each, as in 1960s Mexico, when 'a liberal trade policy toward distribution and exhibiting film imports coincided with a promotive cultural policy, such as active state involvement in production'. Flibbert thus underlines the necessity to 'look below the surface of formal policy pronouncements to see the contours of the ongoing policy-making battles occurring within the state' (Flibbert 2007, 136-7). In the same way, Mattelart et al. warn against any 'monolithic conception of the state as a "cold monster," a disembodied arbitrator of society', since 'the state is itself an integral part of society, affected by all the tensions, and even the contradictions created by the confrontation of social and industrial projects, corporatist interests, but also class interest' (Mattelart et al. 1984, 74). Hence, the importance of considering not only the general public policy discourse, but also the different players involved.

In line with Flew et al.'s observation of media policy, one can consider that there are three main actors in film policies: 'the state (the core executive), the market (private and business actors including the media) and civil society (voluntary and community sector actors)' (Flew et al. 2016, 7). While different state agencies might be pursuing contradictory agendas, private actors are also often divided, with many film battles around the world opposing producers and exhibitors, for example. With globalisation, the number of players has also increased. Iosifidis notes Cariño's remarks on the move from an era of "government" where the state exercised absolute control' to an era of "governance" in which there is a fragmentation of authority and the emergence of new actors', an era in which 'power is mainly shared among national regulatory authorities, international intergovernmental agencies, civil society representatives and the corporate sector' (Iosifidis 2016, 21). The multiple actors and conflicting agendas, however, are rarely the subjects of academic studies. 
By dedicating a whole section to 'Film policy stakeholders' and by including interviews with and texts by film policy actors, this volume aims at bringing to the fore these understudied issues and rarely heard voices.

When one moves the focus away from surface rhetorics onto internal battles, the political dimension of film policies appears fully. At the end of CinEcoSA's 2013 'Film and Television Policies in English-Speaking Countries' conference, the most striking element of the day was less the diversity of state initiatives than the fierce tensions played out in the film policy world. Presenters recounted 'stories of outraged public opinion, of reforms making it to the front page; we heard strongly emotional terms such as being "ridiculed" or "embarrassed," alongside war-like metaphors, such as professionals being "up in arms"' (Mingant 2013). At the centre of film policies is a constant power struggle between the different players. For film professionals, the issue is survival of their industry, whether discussions focus on the economic situation of a specific sector or on freedom of expression. For the state, cinema - as well as culture in general - will tend to be exploited to reach non-film-related objectives. The latter can be economic, such as the development of the strong film and media sector to create employment or the development of media cities as a tool for urban regeneration. They can also be propagandist in nature. Cinema can be used as a means to build a specific identity for the nation, not only through the production of films in line with the state's ideology, but also by privileging the predominance of certain languages and groups. In 1960s Sri Lanka, for example, the state strove to break the monopoly of non-Sinhalese minorities (Muslims, Tamoul, Southern Indians) on the film industry to put it in the hands of Sinhalese (Tampoe-Hautin 2011, 122). The physical space of the movie theatre has also often been turned into a political space, from the surveillance of the audience's reaction by policemen in colonial Tunisia (Corriou 2011, 300) to the 2016 decision by the Indian Supreme Court to have audiences stand up to the national anthem before each film screening. Population control can also be the ultimate objective of apparent film-related decisions, as the debate about the 2015 copyright law in Hong Kong illustrates.

\section{Researching Film Policies}

The highly political stake of film policy and its protean nature make it a difficult object for academics to explore. Sources to be scanned are extremely varied. Secondary sources range from studies on histories of film and film industry in specific countries to volumes on audiovisual translation, culture, capitalism, labour conditions, audience research, media, cultural policy and urbanisation. Press articles are extremely useful with their up-to-date and minute recording of film policy discussions, passing and implementation. Two other sources that academics extensively rely 


\section{Nolwenn Mingant and Cecilia Tirtaine}

on are more problematic. The first is official sources: legislations and decrees, state-commissioned reports on the film industry sector, official speeches, websites of organisation, institutions and stakeholders (trade unions, companies, etc.). Conceived with their own political agenda in mind, all these sources challenge researchers to question the motives behind the information given. The contradictory - and complex - relation to official sources and the constant need to interrogate accepted discourses are explored in this volume by Julia Hammett-Jamart and Joël Augros.

Another problematic source is interviews with stakeholders. While immensely valuable to academics, as interviewers disclose otherwise inaccessible information, they require a strong code of ethics and critical mind. Not only are interviewees answering according to their own vision and agenda, but also their answers are often constrained by the political context they operate in. Many remarks are communicated 'off the record' as public comments on sensitive topics would prove dangerous to the interviewees' career. Academics thus have to process interviews both critically and carefully. The editors would like here to express special thanks to all the industry stakeholders who have taken the time to candidly share their experience and vision, and, in the process, have helped the authors make this volume more meaningful.

An ethical question has also been whether academics should engage or not in the film policy debates. Some academics prefer to take a step back and stand as decipherer of policies, while others have followed the steps of Stuart Cunningham by strongly engaging in the debates. The volume includes chapters by academically-trained contributors who are also film stakeholders. Anna Herold, Patrick Ndiltah and Petar Mitric have, for example, decided to express more committed viewpoints and recommendations. One commitment taken by the editors themselves has been to take stock of the strong inequality in the extent of film policy literature on different geographical areas. While Western countries such as France have tended to be the focus of attention in discussion on film policies, the situations in many countries in Latin America, Asia and Africa have been understudied. One specific attention has thus been to include contributions dealing with countries from the five continents. With this volume, the editors aim at establishing in the current film policy conversation experiences from countries and regions all over the world. Contributors range from a variety of humanities fields, from Film, Television and Media Studies, to Journalism and Communication, Sociology and Cultural Studies.

\section{Book Outline}

Part I examines the traditional film policy paradigm, which has governed state intervention since the birth of cinema. Historical, cultural and economic motives behind policies are studied, in all their complexities and 
ambiguities. Interviewed while he was head of the North-East of Paris Film Commission, Stephan Bender testifies to the various motivations that make attracting foreign shootings vital for a city. In her case study, York shows the cultural battle led by the Quebec government, not only against the US but also against France, to have films dubbed locally. Overpeck analyses the ideological context guiding China's film policies and the link between soft power and Chinese investment in the US exhibition sector. The conversation on soft power is pursued by deWinter, who brings to light the paradoxes of a Cool Japan policy, which relies on exporting a culture that is suppressed at home. Foremost in the film policy battle is the importance of discourse. In his case study, Van Esler offers a thorough analysis of discourses developed after the 2014 Sony hack and shows the intimate link between Hollywood and Washington. Augros's case study examines the side effects of certain regulations and how some players have famously taken advantage of loopholes in different countries' legislations.

Part II focuses on the actions and voices of the various stakeholders participating in the film policy ecosystem, by either creating the policies, benefitting from them or protesting against them. Behind the slickly-designed speeches, authors show the gritty reality of the daily film policy power struggle. Alexandre offers a unique analysis of the sociological profile of French policy-makers and foregrounds both the way this 'French Media Government' works in as a close circle and how the convergence era threatens their hold. Yecies traces the informal collaborations between Chinese and South Korean film-makers that came to be formalised in an official co-production treaty in 2014. Jones foregrounds the agency of professional organisations in pressuring state authorities for new legislations by tracing the initiatives taken by the Indian Association of Bangalore Animation Industry that led to the adoption of an Animation, Visual Effects, Gaming, and Comics Policy in 2011 in the state of Karnataka. Joe Pavlo discusses the VFX industry and the impact tax incentives have had on its development in the UK. He highlights the relevance of unionisation in this sector. TC Li brings the discussion on distribution issues by examining the grassroots distribution techniques of fans of Chinese independent documentaries and their struggle to promote these films in the context of strict state censorship. Hammett-Jamart concludes Part II with a contribution in which academics themselves are cast as stakeholders, locked in an invisible battle over sources with Australian policy-makers.

Part III examines the coexistence of several layers of film policy. Local, national and supranational interventions intertwine, not only complementing each other but also creating overlaps and contradictions. This part opens on the situation in Latin America. Crusafon describes the logic behind the creation of supranational programme Ibermedia and evaluates it by comparing it with other programmes. In his case study, 
González brings to light not only the existence of three levels of state intervention in Argentina today, but also the temporality of their creation, thus contextualising each level of policy. The interview with Lebanese producer Sabine Sidawi changes the perspective, giving the point of view of a policy user, in the geographical context of the Mediterranean. Sidawi tells us how she navigates the complex world of local and regional film support programmes. Three contributions then explore issues played out in the European field. Steele explores the creation of infranational film support mechanisms and the birth of collaborations between localities from neighbouring countries Belgium and France. Mitric gives a critical vision on the harmonised film policies at the European level, examining the impact of Europeanisation on Serbia as it prepares to join the Union and putting it into a historical perspective by reminding the reader of former Yugoslav film policies. This section concludes on a defence by European Commission executive Herold and Golser of the specific 'cultural diversity' model developed by Europe and suggestions on using this model as an inspiration to modify international orientations, especially at the World Trade Organisation level.

In the context of the digital turn and the convergence phenomenon, Part IV shows how the film policy paradigm is currently being not only reinvented in countries with a tradition of state intervention in cinema, but also invented in countries with no such tradition. This section opens on a reflection around discourses, as Wagman dissects the traditional Canadian discourse centred on national identity and the way it is currently challenged by transnational players such as Netflix. Pinto then offers an analysis of the rarely studied exhibition sector. She compares the different ways in which US and French exhibitors and policy-makers have faced the digital challenge, each reaction put in the context of specific film policy traditions. In his case study, Ndiltah brings the discussion of state response to technologies in the specific context of Chad, insisting on the deterioration of the legal distribution sector and the powerlessness of state players. This section then turns to one response of policy-makers in countries with a tradition of film policies: the turn to the 'creative industries' conceptual era. Willems, Biltereyst, Merres and Vande Winkel propose a case study of this transition at the infranational level of the Belgian Flanders region. Kowalik and Meers analyse this transition at the state level in South Africa. Cucco blends his study of the turn to creative industries with an analysis of the coexistence of local, national and regional policy levels in Italy. The last two contributions examine countries in which no film policy tradition existed. Ati describes how models developed within the West African Economic and Monetary Union influenced the creation of a Film Code in Togo. Mingant concludes the volume with an analysis of the 'greenfields media policy model' by analysing how Abu Dhabi, a country with no film history, created a film policy ex nibilo in the first decade of the twenty-first century. 


\section{References}

Corriou, Morgan. 2011. "Un nouveau loisir en situation coloniale: le cinéma dans la Tunisie du Protectorat (1896-1956)." PhD dissertation, supervised by Omar Carlier, Université Paris-Diderot.

Dagnaud, Monique. 2011. "Les BRICs font aussi du cinéma." Telos-eu.com. 12 May. Accessed 21 March 2017. www.telos-eu.com/fr/globalisation/ emergents/les-brics-font-aussi-du-cinema.html.

Flew, Terry, Petros Iosifidis, and Janet Steemers, Eds. 2016. Global Media and National Policies, The Return of the State. New York: Palgrave Macmillan.

Flibbert, Andrew. 2007. Commerce in Culture: States and Markets in the World of Film. New York: Palgrave Macmillan.

Hill, John, and Nobuko Kawashima. 2016. "Introduction: Film Policy in a Globalised Cultural Economy." International Journal of Cultural Policy 22(5):667-672.

Iosifidis, Petros. 2011. Global Media and Communication Policy. Basingstoke: Palgrave Macmillan.

Iosifidis, Petros. 2016. "Globalisation and the Re-emergence of the Regulatory State." In Global Media and National Policies, The Return of the State, edited by Terry Flew, Petros Iosifidis, and Janet Steemers, 16-31. New York: Palgrave Macmillan.

Jedlowksi, Alessandro. 2015. "Film Marketing in Nollywood." In Film Marketing into the Twenty-First Century, edited by Nolwenn Mingant, Cecilia Tirtaine, and Joël Augros, 76-79. London: BFI/Palgrave Macmillan.

Jenkins, Henry. 2006. Convergence Culture: Where Old and New Media Collide. New York: New York University Press.

Johnson, Randal. 1996. "Film Policy in Latin America." In Film Policy: International, National and Regional perspectives, edited by Albert Moran, 128-147. London, New York: Routledge.

Mattelart, Armand, Xavier Delcourt, and Michèle Mattelart. 1984. La Culture contre la démocratie? L'audiovisuel à l'heure transnationale. Paris: La Découverte.

Miller, Tobby, Nitin Golvil, John McMurria, and Richard Maxwell. 2001. Global Hollywood. London: BFI Publishing.

Mingant, Nolwenn. 2010. Hollywood à la conquête du monde: Marchés, stratégies, influences. Paris: CNRS Editions.

Mingant, Nolwenn. 2011. "A New Hollywood Genre: The Global-Local Film.” In Global Media, Culture and Identity: Theory, Cases and Approaches, edited by Rohit Chopra and Radhika Gajjala, 142-155. New York and London: Routledge.

Mingant, Nolwenn. 2013. "Concluding remarks." Presented at the 2013 CinEcoSA Conference, "Film and Television Policies in English-Speaking Countries," Université Paris 8, Paris, 25 October.

Moran, Albert, ed. 1996. Film Policy: International, National and Regional Perspectives. London and New York: Routledge.

Safi, Michel. 2016. "Indian Court Order Cinemas to Play National Anthem before Films.” The Guardian.com. 30 November. Accessed 17 January 2017. www. theguardian.com/world/2016/nov/30/indian-court-orders-cinemas-to-playnational-anthem-before-films. 


\section{Nolwenn Mingant and Cecilia Tirtaine}

Statistics New Zealand. 2013-2014. Screen Industry Survey. Accessed 16 January 2017. www.stats.govt.nz/browse_for_stats/industry_sectors/film_and_ television/ScreenIndustrySurvey_HOTP13-14/Definitions.aspx.

Tampoe-Hautin, Vilasnee. 2011. Cinéma et conflits ethniques au Sri Lanka: vers un cinéma cinghalais 'indigène' (1928 à nos jours). Paris: L'Harmattan.

Tomlison, John. 1991. Cultural Imperialism: A Critical Introduction. Baltimore: The John Hopkins University Press.

UNESCO. 2006. Understanding Creative Industries: Cultural Statistics for Public Policy-Making. Accessed 9 September 2017. www.acpculturesplus.eu/ sites/default/files/2015/03/25/unesco_cultural_statistics_for_public_policy_ making.pdf.

Vlassis, Antonios. 2016. "Bollywood et les limites du soft power indien." Telos-eu.com, 27 October. Accessed 21 March 2017. www.telos-eu.com/fr/ societe/bollywood-et-les-limites-du-soft-power-indien.html.

Waisbord, Silvio. 2016. "The 'post-State' Argument and Its Problems: Lessons from Media Policy Reforms in Latin America." In Global Media and National Policies, The Return of the State, edited by Terry Flew, Petros Iosifidis, and Janet Steemers, 32-48. New York: Palgrave Macmillan. 